\title{
Psihometrijske karakteristike Ljestvice dječje osjetljivosti na okolinu u uzorcima hrvatske djece i adolescenata
}

\author{
Gordana Keresteš ${ }^{1}$, Una Mikac ${ }^{1}$, Claire Sangster Jokić ${ }^{\text {i Jasmina Tomas }}{ }^{1}$ \\ ${ }^{1}$ Sveučilište u Zagrebu, Filozofski fakultet, Odsjek za psihologiju, Zagreb, Hrvatska \\ ${ }^{2}$ Zdravstveno veleučilište, Zagreb, Hrvatska
}

\begin{abstract}
Sažetak
Osjetljivost na okolinu osobina je koja se odnosi na lakoću zamjećivanja informacija o okolini i dubinu njihove obrade. Individualne su razlike u osjetljivosti na okolinu znatne, a stupanj te osjetljivosti određuje pojedinčeve reakcije na pozitivne i negativne čimbenike kojima je izložen. Uloga osjetljivosti na okolinu u razvoju i prilagodbi djece i adolescenata nedovoljno je istražena, velikim dijelom zbog toga što je tek nedavno razvijena prva izravna mjera dječje osjetljivosti na okolinu. Cilj je ovoga rada ispitati psihometrijske karakteristike te mjere, nazvane Ljestvica dječje osjetljivosti na okolinu (Pluess i sur., 2018). U okviru projekta Kako smo? Život u Hrvatskoj u doba korone djeca osnovnoškolske $(N=407)$ i srednjoškolske $(N=307)$ dobi ispunila su Ljestvicu dječje osjetljivosti na okolinu i upitnik ličnosti IPIP-15 online-putem. Ljestvica dječje osjetljivosti na okolinu kao instrument za samoprocjenu osjetljivosti na okolinu pokazala je zadovoljavajuće razine pouzdanosti i valjanosti kod hrvatske djece i adolescenata. Ljestvica ima bifaktorsku strukturu te mjeri opću osjetljivost na okolinu i tri specifične dimenzije: estetsku osjetljivost, nizak osjetni prag i pobudljivost. Utvrđena je djelomična mjerna invarijatnost Ljestvice za djecu različitoga roda i dobi. Korelacije pojedinih dimenzija i opće osjetljivosti na okolinu s osobinama ličnosti umjerene su i teorijski smislene. Ljestvicu je preporučljivo koristiti u budućim istraživanjima, iako su za pojedine podljestvice potrebna daljnja istraživanja. Primjena Ljestvice može doprinijeti povećanju znanja o učincima pozitivnih i negativnih čimbenika iz okoline na razvoj djece $\mathrm{i}$ adolescenata.
\end{abstract}

Ključne riječi: Ljestvica dječje osjetljivosti na okolinu, pouzdanost, valjanost, konfirmatorna faktorska analiza, mjerna invarijatnost

$\square$ Gordana Keresteš, Odsjek za psihologiju, Filozofski fakultet, Sveučilište u Zagrebu, Ivana Lučića 3, 10000 Zagreb, Hrvatska. E-pošta: gkerestes@ffzg.unizg.hr

Rad je nastao u okviru znanstvenih projekata Kako smo? Život u Hrvatskoj u doba korone i Partnerske i obiteljske odrednice psihičkog zdravlja tijekom pandemije koronavirusa, koje dijelom financira Filozofski fakultet Sveučilišta u Zagrebu (sredstva iz Ugovora o namjenskom institucionalnom financiranju znanstvene djelatnosti u 2020. godini).

Zahvaljujemo svim članicama istraživačkoga tima COVIDOVIH 13 na pomoći u prevođenju Ljestvice dječje osjetljivosti na okolinu.

Zahvaljujemo stručnim suradnicima u osnovnim i srednjim školama koji su nam pomogli uključiti učenike u istraživanje. 


\section{Uvod}

U psihologiji je dugo prisutna ideja da su ljudi različito osjetljivi na negativne čimbenike u okolini u kojoj žive. Ta je ideja svoju najjasniju teorijsku artikulaciju dobila unutar modela dijateza - stres (Monroe i Simons, 1991), jednoga od vodećih teorijskih okvira u području psihopatologije. Prema tomu modelu razvoj psihičkih poteškoća rezultat je interakcije pojedinčeve urođene osjetljivosti na negativne čimbenike iz okoline (dijateza) i izloženosti tim čimbenicima (stres). Model dijateza - stres pretpostavlja da isti negativni čimbenici iz okoline imaju različite učinke na različite pojedince. Kad su izloženi takvim čimbenicima, pojedinci koji nisu osjetljivi na njihove utjecaje pokazuju otpornost, dok oni koji su osjetljivi na njih mogu razviti psihičke poteškoće.

U posljednjih nekoliko desetljeća teorijski pogledi na prirodu čovjekove osjetljivosti na okolinu znatno su prošireni. U novijim pristupima ističe se da individualne razlike u osjetljivosti na okolinu ne čine ljude različitima samo u načinu na koji doživljavaju i reagiraju na negativne, već i na pozitivne čimbenike u svojoj okolini. Drugim riječima, dimenzija osjetljivosti na okolinu počela se konceptualizirati kao opća plastičnost organizma koja pojedinca čini prijemčivim za sve utjecaje iz okoline, kako negativne, tako i pozitivne. Unutar takvih teorijskih pristupa posebno se ističu tri modela: model različite podložnosti utjecajima iz okoline (engl. Differential Susceptibility Model; Belsky, 2013; Belsky i sur., 2007; Belsky i Pluess, 2009), model osjetljivosti na osjetne informacije (engl. Sensory Processing Sensitivity; Aron i Aron, 1997; Aron i sur., 2012) i model biološke osjetljivosti na kontekst (engl. Biological Sensitivity to Context; Boyce i Ellis, 2005; Ellis i Boyce, 2008; Ellis i sur., 2005). Ideja o snažnijim pozitivnim učincima povoljne okoline na visoko osjetljive pojedince izdvojila se i kao zaseban teorijski pogled nazvan modelom osjetljivosti na povoljne okolnosti (engl. Vantage Sensitivity; de Villiers i sur., 2018; Pluess, 2017; Pluess i Belsky, 2013). Iako se navedene teorije međusobno znatno razlikuju, sve one ističu da osjetljivost na okolinu nije povezana samo s doživljavanjem negativnih aspekata okoline i s razvojem psihopatologije, već i s reakcijama na pozitivne aspekte okoline i s pozitivnim razvojnim ishodima.

Michael Pluess, profesor razvojne psihologije s londonskoga sveučilišta Queen Mary, nedavno je napravio važan korak u teorijskoj razradi konstrukta osjetljivosti na okolinu ponudivši metateorijski okvir kojim je integrirao postavke ranijih modela osjetljivosti na okolinu, oslanjajući se pritom na opće postavke razvojne i evolucijske psihologije (Pluess, 2015). Prema Pluessu osjetljivost na okolinu sposobnost je zamjećivanja informacija o okolini i njihove obrade. Svojstvena je većini živih bića i jedna je od njihovih temeljnih odlika važnih za ontogenetsku i evolucijsku prilagodbu. Iako je osjetljivost na okolinu od velike važnosti za prilagodbu svake jedinke na specifičan kontekst $u$ kojemu živi i razvija se, različite su jedinke različito osjetljive na okolinu. Te individualne razlike proizlaze iz genetski određenih razlika 
u osjetljivosti središnjega živčanog sustava. Prema tome, razlike u osjetljivosti središnjega živčanog sustava dovode do razlika u lakoći kojom različite jedinke zamjećuju informacije o svojoj okolini, kao i do razlika u dubini obrade tih informacija. Pojedinci s osjetljivijim živčanim sustavom lakše zamjećuju i dublje obrađuju informacije o svojoj okolini. Kao i u teorijama koje je integrirao, Pluess je i u svojemu metateorijskom okviru konceptualizirao osjetljivost na okolinu kao osobinu ličnosti koja određuje pojedinčeve reakcije na ukupan raspon kvalitete fizičkih i psihosocijalnih podražaja i događaja u okolini, kako onih negativnih koji ugrožavaju dobrobit i razvoj, tako i onih pozitivnih koji ih promoviraju.

Osjetljivost na okolinu od velike je važnosti za razumijevanje razvoja djece i adolescenata. Iako su u razvojnoj psihologiji razmjerno dobro utvrđeni štetni učinci negativnih čimbenika iz okoline, poput niskoga socioekonomskog statusa obitelji i siromaštva (npr. Sušac i sur., 2016), neadekvatnoga roditeljstva i loših odnosa u obitelji (npr. Rajhvajn Bulat i sur., 2019; Sušac i sur., 2016), nekvalitetnih odnosa s vršnjacima (npr. Rajhvajn Bulat i sur., 2019) ili stresnih i traumatskih ratnih iskustava (npr. Keresteš, 2006; Kuterovac Jagodić, 2003), kao i povoljni učinci pozitivnih čimbenika iz okoline, poput podržavajućega roditeljstva i dobrih odnosa s vršnjacima (npr. Raboteg-Šarić i sur., 2018), posjedovanja kućnoga ljubimca (npr. Vizek-Vidović i sur., 2001) ili dobro osmišljenih i znanstveno utemeljenih psiholoških intervencija (npr. Rončević Zubković i sur., 2020) na razvoj u djetinjstvu $i$ adolescenciji, malo se zna o mogućim razlikama u veličini tih učinaka ovisno o djetetovoj općoj osjetljivosti na okolinu. U dosadašnjim istraživanjima učinci čimbenika okoline na ponašanje i razvoj pretežno su utvrđivani u općim uzorcima djece i adolescenata, pri čemu su zanemarivane moguće razlike u reakcijama djece različito osjetljive na okolinu na iste čimbenike. Takvo zanemarivanje uloge osjetljivosti na okolinu rezultira nepotpunim znanjem o učincima okoline na razvoj. Naime, u općim se uzorcima razlike među djecom koja su različito osjetljiva na okolinu međusobno poništavaju te učinci utvrđeni za cijeli uzorak predstavljaju precijenjenu procjenu učinaka za djecu koja su slabo osjetljiva na okolinu i podcijenjenu procjenu za djecu koja su visoko osjetljiva na okolinu.

Jedan od glavnih preduvjeta napretka u području istraživanja osjetljivosti na okolinu i njezine uloge u razvoju djece i adolescenata raspolaganje je valjanim i pouzdanim mjerama toga konstrukta. Osjetljivost na okolinu manifestira se na različitim razinama funkcioniranja, uključujući genetsku, fiziološku i psihološkoponašajnu. $U$ dosadašnjim su istraživanjima na svakoj od tih razina korištene mnoge varijable kao indikatori osjetljivosti na okolinu. Na psihološkoj razini dječja je osjetljivost na okolinu sve do prije nekoliko godina bila mjerena neizravno, odnosno o njoj se zaključivalo na temelju drugih konstrukata, najčešće temperamenta (Cassidy i sur., 2011; Kim i Kochanska, 2012; Pluess i Belsky, 2009; Slagt i sur., 2016) i ličnosti (De Haan i sur., 2010; Ho i sur., 2013; Slagt i sur., 2015).

Prvu izravnu mjeru osjetljivosti na okolinu za djecu i adolescente, Ljestvicu dječje osjetljivosti na okolinu (engl. Highly Sensitive Child Scale; u daljnjemu tekstu 
Ljestvica DOO), razvio je Pluessov istraživački tim 2018. godine. Ljestvica je namijenjena djeci i adolescentima u dobi od 8 do 20 godina i temelji se na samoprocjenama. Nastala je adaptacijom Ljestvice osjetljivosti na okolinu za odrasle (engl. Highly Sensitive Person Scale; Aron i Aron, 1997; hrvatski prijevod Hanzec i sur., 2017), razvijene u okviru modela osjetljivosti na osjetne informacije. U usporedbi s neizravnim mjerama dječje osjetljivosti na okolinu Ljestvica DOO znatno šire zahvaća konstrukt osjetljivosti na okolinu. Iako se sastoji od svega 12 čestica, obuhvaća tri komponente opće osjetljivosti na okolinu identične komponentama koje mjeri Ljestvica osjetljivosti na okolinu za odrasle: estetsku osjetljivost (engl. Aesthetic Sensitivity), nizak osjetni prag (engl. Low Sensory Threshold) i pobudljivost (engl. Ease of Excitation). Estetska osjetljivost odnosi se na svjesnost estetskih aspekata okoline i dubinu obrade umjetničkih sadržaja, nizak osjetni prag na neugodnu pobuđenost izazvanu intenzivnim vanjskim podražajima poput glasnih zvukova i jakih svjetala, a pobudljivost na lakoću kojom pojedinac postane preplavljen podražajima i zahtjevima iz okoline, kao što je zahtjev da mnogo toga treba učiniti odjednom.

U dosadašnjim primjenama Ljestvica DOO pokazala je bifaktorsku strukturu s jednim općim faktorom osjetljivosti na okolinu i trima očekivanima specifičnim faktorima (estetska osjetljivost, nizak osjetni prag i pobudljivost). Psihometrijske karakteristike u različitim uzorcima djece $i$ adolescenata iz Ujedinjenoga Kraljevstva (Pluess i sur., 2018) i Belgije (Weyn i sur., 2019) pokazale su se zadovoljavajućima. Utvrđene su određene dobne i rodne razlike u rezultatima, pri čemu su djevojčice i mlađa djeca postizali više rezultate, odnosno imali veću osjetljivost na okolinu, iako su učinci bili mali.

Primjenom Ljestvice DOO potvrđuju se hipoteze Pluessova (2015) metateorijskog okvira osjetljivosti na okolinu. Primjerice, $u$ evaluaciji intervencije provedene u talijanskim osnovnim školama s ciljem smanjenja vršnjačkoga nasilja pokazalo se da je intervencija imala pozitivne učinke na dječake koji su visoko osjetljivi na okolinu, ali ne i na one koji su slabo osjetljivi na okolinu (Nocentini i sur., 2018). Nizozemski istraživači (Slagt i sur., 2018) prilagodili su Ljestvicu DOO da bi prikupili majčine procjene za osjetljivost predškolske djece $i$ ispitali moderira li djetetova osjetljivost na okolinu učinke pozitivnih i negativnih roditeljskih odgojnih postupaka na djetetov razvoj. Longitudinalnim praćenjem utvrdili su da je kod djece koju su majke procijenile visoko osjetljivom na okolinu količina eksternaliziranih problema bila povezana s promjenama u pozitivnim i negativnim roditeljskim postupcima. Eksternalizirani problemi djece koju su majke procijenile nisko osjetljivom na okolinu nisu bili povezani s promjenama u roditeljskome ponašanju. Rezultati obaju istraživanja pokazuju da razvoj djece koja su visoko osjetljiva na okolinu, u usporedbi s razvojem djece koja su manje osjetljiva na okolinu, u većoj mjeri ovisi o čimbenicima u okolini, kako onima koji su pozitivni, tako i onima koji su negativni. 
Cilj je ovoga rada ispitati mogu li se Ljestvicom DOO pouzdano i valjano mjeriti individualne razlike u osjetljivosti na okolinu u uzorcima hrvatske djece i adolescenata, odnosno utvrditi psihometrijske karakteristike hrvatskoga prijevoda te ljestvice. U okviru provjere konstruktne valjanosti ispitane su korelacije ukupnoga rezultata i rezultata na podljestvicama Ljestvice DOO s osobinama ličnosti iz modela „Velikih pet”. Teorijska razmatranja konstrukta osjetljivosti na okolinu (npr. Pluess, 2015) i dosadašnje validacije Ljestvice DOO (Pluess i sur., 2018; Weyn i sur., 2019) pokazuju da je osjetljivost na okolinu osobina ličnosti višega reda čija se pojedina obilježja manifestiraju u drugim psihološkim konstruktima, prije svega temperamentu i ličnosti, iako se u njima ne iscrpljuju. Stoga se očekuju umjerene korelacije između osobina ličnosti i rezultata na Ljestvici DOO, pri čemu su od posebne važnosti korelacije podljestvice estetske osjetljivosti, kao mjere osjetljivosti na pozitivne aspekte okoline, s osobinama ličnosti povezanima $s$ tendencijom prilaženja pozitivnim, nagrađujućim i ugodnim iskustvima (ekstraverzija, intelekt i ugodnost) te korelacije podljestvica niskoga osjetnog praga i pobudljivosti, kao mjera osjetljivosti na negativne aspekte okoline, s osobinama ličnosti povezanima $\mathrm{s}$ tendencijom izbjegavanja neugodnih ili nenagrađujućih iskustava (neuroticizam i introverzija).

\section{Metoda}

\section{Sudionici}

Sudionici u ovome istraživanju dolaze iz dvaju prigodnih uzoraka iz opće učeničke populacije u Republici Hrvatskoj. U istraživanju je sudjelovalo 407 učenika osnovnih škola (50.5\% djevojčica) i 307 učenika srednjih škola (60.5\% djevojaka). U uzorku su razmjerno ravnomjerno zastupljena djeca svih obrazovnih razina (broj djece po pojedinim razrednim razinama kreće se od 30 za 1. i 2. razred osnovne do 111 za 2. razred srednje škole). Kronološka dob kretala se od 7 do 20 godina.

\section{Instrumenti}

\section{Ljestvica dječje osjetljivosti na okolinu}

Ljestvica DOO hrvatska je adaptacija instrumenta Highly Sensitive Child (HSC) Scale (Pluess i sur., 2018) koji mjeri samoiskazanu osjetljivost na okolinu djece i adolescenata u dobi od 8 do 20 godina. Instrument sačinjava 12 čestica. Sudionici na ljestvici od sedam stupnjeva iskazuju procjenu koliko ih dobro opisuju određene rečenice $(1=$ uopće ne; $4=$ umjereno; $7=$ izrazito $)$. Instrument se sastoji od triju podljestvica: pobudljivost (5 čestica), estetska osjetljivost (4 čestice) i nizak osjetni prag (3 čestice). 


\section{IPIP-15}

IPIP-15 je upitnik koji mjeri „Velikih pet” osobina ličnosti djece i adolescenata. Razvijen za potrebe projekta Kako smo? Život u Hrvatskoj u doba korone, IPIP-15 koristi 15 od 50 čestica iz hrvatskoga upitnika IPIP Junior (Mlačić i sur., 2007). Paralelna analiza (Garrido i sur., 2013; O’Connor, 2000) ukazuje na postojanje pet faktora koji se sastoje od pretpostavljenih čestica i čija se zasićenja nakon Varimax rotacije kreću od .29 do .88 . Neke od skala pokazuju nešto niže razine pouzdanosti tipa unutarnje konzistencije (Tablica 3.), vjerojatno jer je riječ o vrlo kratkim skalama gdje se svaka osobina ličnosti mjeri trima česticama. Slične razine pouzdanosti tipa unutarnje konzistencije dobila je i Zadro (2020) prilikom korištenja sličnih kratkih ljestvica osobina ličnosti (TIPI), no također je pokazala da su test - retest pouzdanosti više i zadovoljavajuće, a one se mogu smatrati boljim pokazateljima pouzdanosti za tako kratke skale.

\section{Postupak}

\section{Prijevod i adaptacija hrvatske verzije Ljestvice DOO}

Hrvatski prijevod i adaptacija Ljestvice DOO provedeni su u pet koraka prema postupku opisanome u protokolu koji su pripremili autori skale (Pluess, 2020). Adaptaciju su izvršile izvorne govornice hrvatskoga jezika s izvrsnim poznavanjem engleskoga jezika koje su imale stručna i znanstvena znanja povezana sa sadržajem ljestvice. Faze su toga procesa bile sljedeće: 1) dva neovisna prijevoda s engleskoga na hrvatski jezik; 2) sinteza hrvatskih prijevoda; 3 ) dva neovisna povratna prijevoda s hrvatskoga na engleski jezik; 4) sinteza engleskih povratnih prijevoda koju je koordinirala izvorna govornica engleskoga jezika; i 5) pregled točnosti i kulturološke prikladnosti prethodnih prijevoda i izrada konačne verzije Ljestvice DOO. U svim fazama sinteze sudionici su raspravljali i bilježili sva pitanja i nedoumice koje su koristili u sljedećim fazama u pripremi konačne hrvatske verzije.

\section{Prikupljanje podataka}

Metodom snježne grude, objavama na društvenim mrežama i u medijima sudionici su regrutirani za veliku anketu provedenu u okviru projekta Kako smo? Život u Hrvatskoj $u$ doba korone čiji je cilj ispitati posljedice pandemije bolesti COVID-19 i potresa na psihičko zdravlje građana Hrvatske. Projekt uključuje upitnike namijenjene različitim segmentima opće populacije, uključujući učenike osnovnih i srednjih škola. Prikupljanje svih podataka provedeno je u svibnju 2020. godine. Budući da je to razdoblje bilo vrijeme zatvaranja (lockdowna) u Hrvatskoj, provedba istraživanja odvijala se isključivo online. Etičko odobrenje za provedbu istraživanja dalo je Etičko povjerenstvo Odsjeka za psihologiju Filozofskoga fakulteta Sveučilišta u Zagrebu. 
Jedan dio uzorka korištenoga u ovome istraživanju regrutiran je preko roditelja. Nakon što je roditelj ispunio upitnik za odrasle, dobio je pozivnicu za djetetovo sudjelovanje u istraživanju. Uz pristanak roditelja, djeca su dala i vlastiti pristanak za sudjelovanje, nakon čega su im prikazana različita pitanja, uključujući Ljestvicu DOO i IPIP-15. Drugi dio uzorka regrutiran je putem pozivnica upućenih stručnim suradnicima u osnovnim i srednjim školama. Uz odobrenje ravnatelja, stručni suradnici ili razrednici prosljeđivali su poziv roditeljima i učenicima škole. I u tome je načinu regrutiranja učenika roditelj prije djetetova pristupanja upitniku trebao iskazati svoju suglasnost za to.

Upitnik je strukturiran tako da su sva djeca na početku ispunila prvi dio u koji je uključena Ljestvica DOO, nakon čega su birala žele li ispuniti i dva dodatna dijela upitnika, od kojih je jedan uključivao IPIP-15. Zbog takvoga načina strukturiranja upitnika IPIP-15 ispunila su samo ona djeca koja su odlučila ispuniti taj dio upitnika. Stoga je IPIP-15 ispunio manji broj djece (177 osnovnoškolaca i 161 srednjoškolac) od one koja su ispunila Ljestvicu DOO. Između djece koja su ispunila oba upitnika i one koja su odgovorila samo na Ljestvicu DOO postoje male, iako statistički značajne razlike: djeca koja su ispunila oba upitnika u prosjeku su 10 mjeseci starija $(t(708)=3.48, p<.001)$, među njima je više djevojčica $\left(61 \%\right.$ naspram $49 \%, \chi^{2}(2)$ $=11.41, p=.003)$, ujednačenija su po stupnju školovanja (52\% osnovnoškolaca naspram $61 \%$ osnovnoškolaca, $\left.\chi^{2}(1)=5.28 p=.021\right)$ te imaju za 0.17 bodova viši prosječni rezultat na cijeloj Ljestvici DOO $(t(703)=2.47, p=.014)$ i za 0.23 boda na podljestvici estetske osjetljivosti $(t(703)=3.66, p<.001)$.

\section{Analiza podataka}

U prvome koraku analize podataka u cjelokupnome je uzorku ispitana faktorska struktura Ljestvice DOO. U tu svrhu konfirmatornim faktorskim analizama testirali smo i usporedili dva modela: (i) trofaktorski model koji je podrazumijevao postojanje triju međusobno povezanih faktora (estetska osjetljivost, nizak osjetni prag i pobudljivost) te (ii) teorijski očekivan bifaktorski model koji je pored triju prethodno navedenih faktora sadržavao i jedan opći faktor osjetljivosti na okolinu. Latentna struktura bifaktorskih modela podrazumijeva da je svaka čestica istovremena zasićena jednim specifičnim te jednim općim faktorom koji objašnjava dio varijance svake čestice u modelu (Reise i sur., 2013). Specifični su faktori međusobno neovisni, odnosno korelacija između njih fiksirana je na 0 . U obama modelima estetska osjetljivost operacionalizirana je s četirima česticama, nizak osjetni prag s trima česticama, a pobudljivost s pet čestica, dok je dodatni opći faktor osjetljivosti na okolinu u bifaktorskome modelu operacionaliziran pomoću svih 12 čestica.

Nakon provjere faktorske strukture na modelu koji je pokazao bolje pristajanje podacima u prethodnome koraku ispitana je mjerna invarijatnost Ljestvice DOO s obzirom na rod i dob, odnosno obrazovnu razinu (osnovna i srednja škola). Provjera mjerne invarijatnosti testira pretpostavku da instrument mjeri isti konstrukt $\mathrm{u}$ 
različitim poduzorcima, što je preduvjet usporedbe pojedinih skupina po osjetljivosti na okolinu - u ovome slučaju djevojčica i dječaka te djece osnovnoškolskoga i srednjoškolskog uzrasta. Prilikom testiranja invarijatnosti testirali smo u tri sukcesivna podkoraka jesu li u obama poduzorcima jednake faktorske strukture (konfiguralna invarijatnost), faktorska zasićenja (metrijska invarijatnost) te odsječci (intercepti - skalarna invarijatnost; Little, 2013). Ako nije utvrđena potpuna invarijatnost u tim podkoracima, moguće je pokušati postići djelomičnu invarijatnost testiranjem razlikuju li se samo neki od parametara (primjerice, odsječak) između skupina. Djelomična metrijska invarijatnost pruža podlogu za donošenje zaključka da instrument $u$ određenoj mjeri predstavlja isti konstrukt $u$ različitim skupinama (Little, 2013).

U trećemu koraku analize podataka ispitali smo pouzdanost tipa unutarnje konzistencije koristeći tri koeficijenta - Cronbachov alfa $(\alpha)$, omega $(\omega)$ i hijerarhijski omega $\left(\omega_{\mathrm{H}}\right)$ koeficijent (McDonald, 1999). Prilikom računanja Cronbachova alfa koeficijenta pretpostavlja se da su sve čestice jednako zasićene faktorom, što ovdje nije slučaj, te je omega koeficijent prikladniji pokazatelj pouzdanosti (Dunn i sur., 2014). Cronbachovu alfu prikazujemo radi usporedivosti s prethodnim istraživanjima. Hijerarhijski omega pokazatelj je koliko varijance možemo pripisati pojedinomu faktoru i najznačajniji je za evaluaciju doprinosa podljestvica.

U posljednjemu su koraku izračunani kompozitni rezultati na svim trima podljestvicama i cijeloj ljestvici, njihove interkorelacije te korelacije s „Velikih pet” osobina ličnosti.

Analize su provedene u programu R (paketi lavaan, semTools, MBESS, psych, Hmisc; R Core Team, 2017; RStudio Team, 2016). Za procjenu vrijednosti parametara konfirmatornih modela korištena je metoda maksimalne vjerojatnosti (engl. maximum likelihood) $\mathrm{s}$ robusnim standardnim pogreškama. Procjena prihvatljivosti pristajanja modela podacima temeljena je na kombinaciji standardnih pokazatelja pristajanja u skladu s uvriježenim kriterijima (RMSEA < .08; CFI i TLI $>$.90; SRMR < .09; Weston i Gore, 2006). Prilikom zaključivanja koji od modela bolje opisuje podatke koristili smo značajnost Satorra-Bentlerova testa razlike u hikvadrat testu (Satorra i Bentler, 2001), kao i veličinu razlike u kriterijima CFI ( $\Delta$ CFI $>.010)$, RMSEA $(\triangle$ RMSEA $>.015)$ te SRMR $(\Delta$ SRMR $>.010)$, s obzirom na to da je Satorra-Bentlerov test često značajan i kod zanemarivih razlika kod relativno velikih uzoraka (Chen, 2007).

\section{Rezultati}

\section{Faktorska struktura i mjerna invarijatnost Ljestvice DOO}

Teorijski očekivan bifaktorski model pokazao je zadovoljavajuće pristajanje podacima (Tablica 1.). Nadalje, taj je model statistički značajno bolje pristajao podacima u odnosu na alternativni trofaktorski model potvrđujući važnost općega 


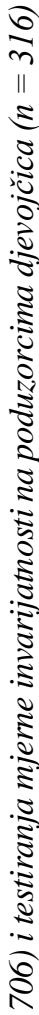

11.

¿

专.

용

$\approx *$

$\frac{2}{5}$

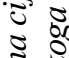

$\frac{5}{2}$

离

\&

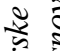

के

3

2.8

$\approx \gamma$

$5 \pm$

纺

is

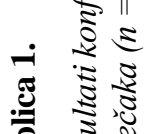

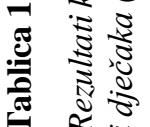

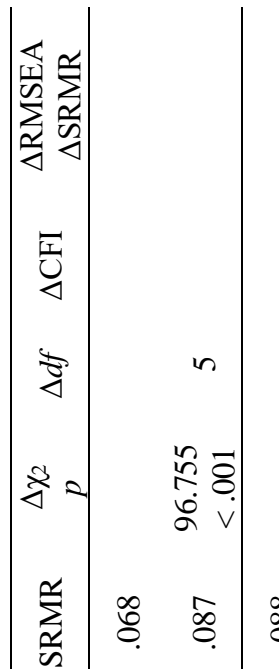

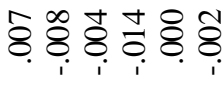

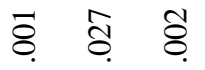

ㅇำ

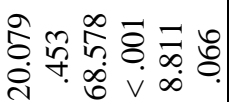

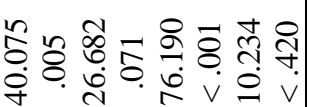

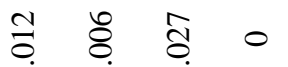

응

$\stackrel{0}{\ddots} \stackrel{\infty}{\circ}$

ڤ

ริ

के

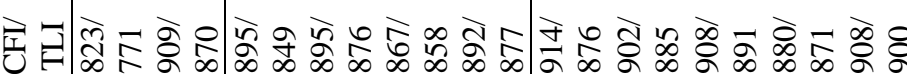

《च च

《चี

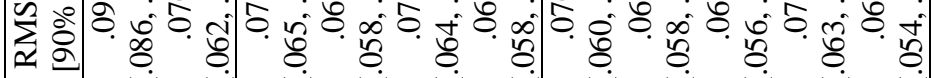
군.

$\rightarrow$

ส่

$\cong$

咅

2

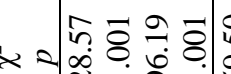

유

8)

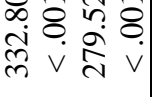

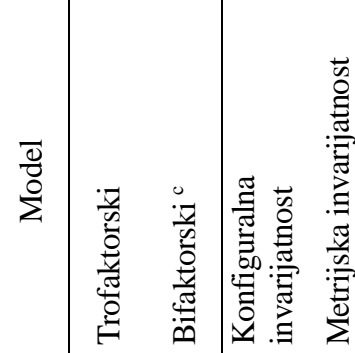

离

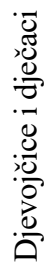

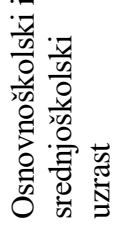

\&

ㅎำ

ค็

:

莺节

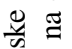

:

흘

递

:

论

के

으 응

욜

(0)

is

ㅋำ

웜

胥

초유.․․ㄹ

产 $\frac{\bar{d}}{\frac{0}{0}}$

a

武

ठํㅎㅁ

क्षे

: 要

क.

क हैं

宁苛

흐음을

용 
faktora osjetljivosti na okolinu. Značajna zasićenja pokazuju da sve čestice odražavaju zajednički opći faktor osjetljivosti na okolinu (Tablica 2.), iako čestice estetske osjetljivosti manje doprinose općemu faktoru (.099 do .196) nego ostale čestice (.414 do .834). Slično su utvrdili Weyn i suradnici (2019). Oni su također pokazali da dvije čestice pobudljivosti imaju niža (neznačajna) zasićenja (.032 i -.020) s predviđenim specifičnim faktorom, iako dosta visoka s općim faktorom. Ostale čestice imaju umjerena do visoka zasićenja pretpostavljenim specifičnim faktorom (od .117 do .743).

Kad je riječ o invarijatnosti između djevojčica i dječaka, dobiveni rezultati govore u prilog konfiguralnoj i metrijskoj invarijatnosti te djelomičnoj invarijatnosti odsječaka (Tablica 1.). Specifičnije, početni model $\mathrm{s}$ jednakim faktorskim strukturama zadovoljavajuće je pristajao podacima te daljnje fiksiranje faktorskih zasićenja jednakima u dvije skupine nije rezultiralo značajnim pogoršanjem pristajanja modela podacima. Međutim, model $\mathrm{s}$ dodatno fiksiranim odsječcima značajno je lošije pristajao podacima u odnosu na model metrijske invarijatnosti. Model djelomične skalarne invarijatnosti pristajao je podacima jednako dobro kao i model s invarijatnim faktorskim zasićenjima tek kad je dopušteno da se osam odsječaka razlikuje između djevojčica i dječaka (Tablica 2.).

Testiranje invarijatnosti $\mathrm{s}$ obzirom na obrazovnu razinu potvrdilo je konfiguralnu te djelomičnu metrijsku i skalarnu invarijatnost (Tablica 1.). Fiksiranje svih faktorskih zasićenja jednakima između osnovnoškolske i srednjoškolske djece značajno je pogoršalo pristajanje $\mathrm{u}$ odnosu na konfiguralni model. Djelomična metrijska invarijatnost potvrđena je nakon oslobađanja faktorskoga zasićenja čestice 6 (Tablica 2.). Model sa svim jednakim odsječcima pristajao je podacima značajno lošije u odnosu na model s djelomičnom metrijskom invarijatnošću. Međutim, dodatno oslobađanje dvaju odsječaka (čestice 5 i 7) dovelo je do djelomične skalarne invarijatnosti između djece osnovnoškolskoga i srednjoškolskog uzrasta.

\section{Tablica 2.}

Prikaz čestica upitnika i faktorskih zasićenja dobivenih pristajanjem bifaktorskoga modela

\begin{tabular}{|c|c|c|c|c|}
\hline \multirow{2}{*}{ Čestica } & \multirow{2}{*}{ Podljestvica } & \multicolumn{2}{|c|}{ Zasićenja faktorom } & \multirow{2}{*}{$\begin{array}{c}\text { Neinvarijatne } \\
\text { čestice }\end{array}$} \\
\hline & & Općim & Specifičnim & \\
\hline $\begin{array}{l}\text { 1. Primijetim kad se male stvari } \\
\text { promijene u mojoj okolini. }\end{array}$ & EO & $.196^{* * * *}$ & $.597^{\mathrm{a}}$ & $\mathrm{s}$ \\
\hline 3. Volim ugodne mirise. & $\mathrm{EO}$ & $.189^{* * *}$ & $.62^{* * * *}$ & $\mathrm{~s}$ \\
\hline $\begin{array}{l}\text { 5. Neka me glazba zaista može } \\
\text { usrećiti. }\end{array}$ & EO & $.099^{*}$ & $.485^{* * *}$ & $\mathrm{~s}^{\mathrm{b}}, \mathrm{o}$ \\
\hline 10. Volim fine okuse. & $\mathrm{EO}$ & $.151^{* *}$ & $.577^{* * *}$ & \\
\hline $\begin{array}{l}\text { 2. Glasni zvukovi stvaraju mi } \\
\text { nelagodu. }\end{array}$ & NOP & $.548^{* * *}$ & $.487^{\mathrm{a}}$ & $\mathrm{s}$ \\
\hline $\begin{array}{l}\text { 7. Ne volim gledati TV programe u } \\
\text { kojima ima mnogo nasilja. }\end{array}$ & NOP & $.414^{* * * *}$ & $.117^{*}$ & $\mathrm{~s}, \mathrm{o}$ \\
\hline 11. Ne volim glasne zvukove. & NOP & $.494^{* * * *}$ & $.734^{* * * *}$ & \\
\hline
\end{tabular}


Keresteš, G., Mikac, U., Sangster Jokić, C., Tomas, J.

Ljestvica dječje osjetljivosti na okolinu

\begin{tabular}{|c|c|c|c|c|}
\hline \multirow{2}{*}{ Čestica } & \multirow{2}{*}{ Podljestvica } & \multicolumn{2}{|c|}{ Zasićenja faktorom } & \multirow{2}{*}{$\begin{array}{l}\text { Neinvarijatne } \\
\text { čestice }\end{array}$} \\
\hline & & Općim & Specifičnim & \\
\hline $\begin{array}{l}\text { 4. Postanem živčan/živčana kad } \\
\text { moram napraviti mnogo toga u } \\
\text { kratkome vremenu. }\end{array}$ & POB & $.537^{\mathrm{a}}$ & $.537^{\mathrm{a}}$ & $\mathrm{s}$ \\
\hline $\begin{array}{l}\text { 6. Živcira me kad drugi od mene } \\
\text { traže da previše toga radim } \\
\text { odjednom. }\end{array}$ & POB & $.449^{* * * *}$ & $.743^{* * *}$ & $\mathrm{O}^{\mathrm{c}}$ \\
\hline $\begin{array}{l}\text { 8. Nije mi ugodno kad se odjednom } \\
\text { događa mnogo toga. }\end{array}$ & POB & $.834^{* * * *}$ & .032 & $\mathrm{~s}$ \\
\hline $\begin{array}{l}\text { 9. Ne volim kad se stvari mijenjaju } \\
\text { u mojemu životu. }\end{array}$ & POB & $.645^{* * *}$ & -.02 & \\
\hline $\begin{array}{l}\text { 12. Postanem nervozan/nervozna kad } \\
\text { me netko gleda dok nešto radim. } \\
\text { Zbog toga to napravim lošije } \\
\text { nego inače. }\end{array}$ & POB & $.481^{* * *}$ & $.192^{* * *}$ & s \\
\hline
\end{tabular}

Napomena: Kod svih su čestica neinvarijatni odsječci, osim ${ }^{\mathrm{c}}$ kod koje je neinvarijatno zasićenje s POB. POB - pobudljivost; EO - estetska osjetljivost; NOP - nizak osjetni prag; s - po spolu; o - po obrazovnoj razini; ${ }^{\mathrm{a}}$ - parametar fiksiran na $1 ;^{\mathrm{b}}$ - parametar je invarijatan ako je kriterij značajnosti promjena u CFI/RMSEA/SRMR. ${ }^{*} p<.05 .{ }^{* *} p<.01 .{ }^{* * *} p<.001$.

Zaključno, rezultati testiranja faktorske strukture hrvatske verzije Ljestvice DOO govore $\mathrm{u}$ prilog pretpostavljenoj bifaktorskoj strukturi, no s obzirom na veličine zasićenja, treba biti oprezan prilikom korištenja podljestvice pobudljivosti. Ostvarena razina metrijske invarijatnosti opravdava usporedbu povezanosti između skupina različitoga roda i uzrasta, no usporedba manifestnih aritmetičkih sredina opravdana je samo za skupine različitoga uzrasta, ali ne i roda gdje nije ostvarena skalarna invarijatnost u većoj mjeri (Putnick i Bornstein, 2016).

\section{Pouzdanost Ljestvice DOO}

Oba pokazatelja pouzdanosti ( $\alpha$ i $\omega$; Tablica 3.) očekivanih su i zadovoljavajućih razina s obzirom na prethodna istraživanja (Pluess i sur., 2018; Weyn i sur., 2019). Hijerarhijski omega koeficijenti pokazuju da specifični faktori uglavnom objašnjavaju mali dio varijance, dovodeći u pitanje korištenje samostalnih podljestvica. Jedino se za podljestvicu estetske osjetljivosti čini da ima svoj specifični doprinos $\left(\omega_{\mathrm{H}}=.83\right)$, no ta se podljestvica pak ističe nižom pouzdanošću $(\omega=.57)$. Zaključno, pokazatelji pouzdanosti podržavaju korištenje ljestvice, ali u manjoj mjeri i podljestvica. 


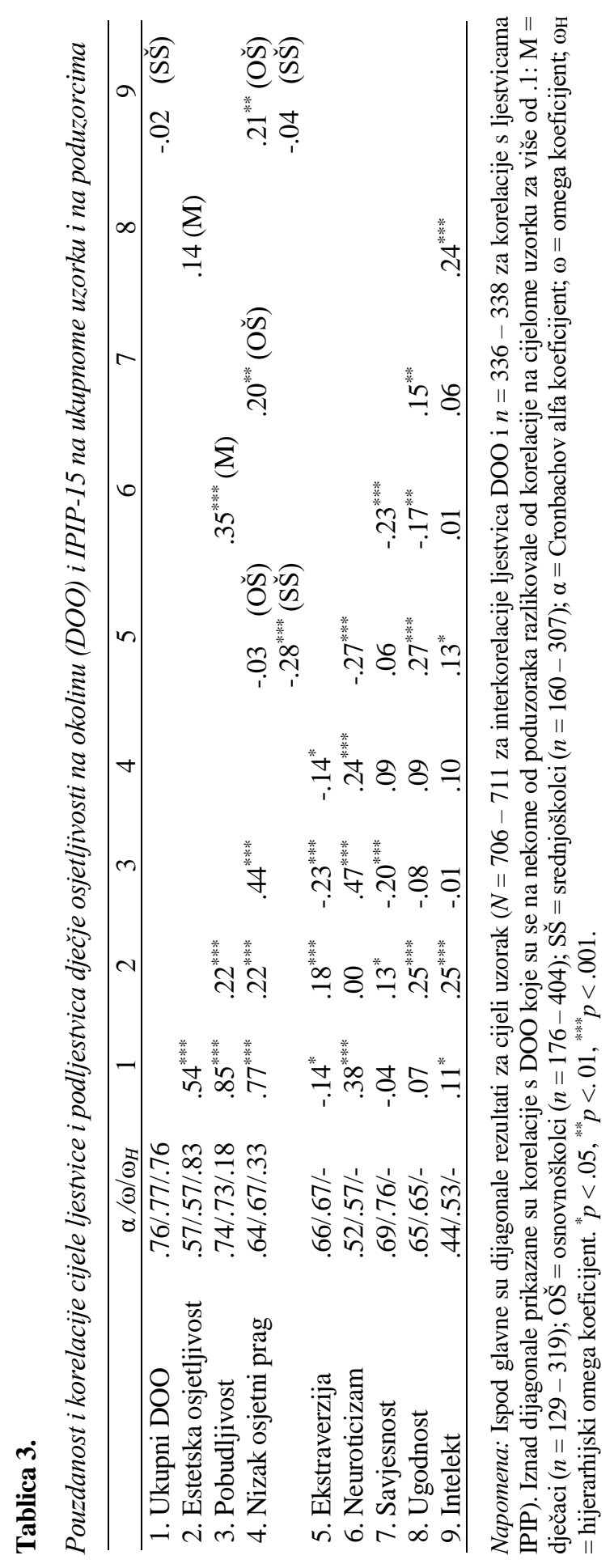




\section{Deskriptivna statistika i bivarijatne korelacije}

Rezultati u Tablici 4. pokazuju da ukupni rezultati na ljestvici i podljestvicama pokrivaju cijeli raspon i imaju lagano do umjereno negativno asimetričnu distribuciju. Pearsonovi koeficijenti korelacije pokazuju slične trendove kao i u prethodnim istraživanjima (Pluess i sur., 2018; Weyn i sur., 2019). Prvo, podljestvica estetske osjetljivosti ima relativno niske, no još uvijek značajne pozitivne korelacije s ostalim podljestvicama (Tablica 3.). Drugo, cijela ljestvica, kao i podljestvice (uz iznimku estetske osjetljivosti), najviše korelira s neuroticizmom (pri čemu su te korelacije pozitivne) i zatim ekstraverzijom (pri čemu su te korelacije negativne). Podljestvica estetske osjetljivosti nije u korelaciji s neuroticizmom, dok je s ekstraverzijom u pozitivnoj korelaciji. Veličine korelacija s neuroticizmom kreću se od relativno niskih (s podljestvicom nizak prag osjetljivosti) do visokih (s podljestvicom pobudljivost), dok ekstraverzija relativno nisko korelira s ukupnim rezultatom na ljestvici, kao is rezultatima na svim podljestvicama. Većina korelacija s ugodnošću i savjesnošću nije značajna. Iznimku predstavljaju značajne te relativno niske korelacije između savjesnosti i podljestvice pobudljivosti (koja je negativnoga predznaka) te podljestvice estetske osjetljivosti (koja je pozitivnoga predznaka), kao i korelacija ugodnosti i podljestvice estetske osjetljivosti (koja je pozitivnoga predznaka). Intelekt nisko, ali statistički značajno pozitivno korelira s ukupnim rezultatom na Ljestvici i rezultatom na podljestvici estetske osjetljivosti. Korelacije dobivene na cijelome uzorku slične su onima na pojedinim skupinama, pogotovo kod djevojčica i srednjoškolaca (Tablica 3.). Najveća su odstupanja nešto više korelacije niskoga osjetnog praga s većinom osobina ličnosti kod osnovnoškolaca te neznačajna povezanost ugodnosti i estetske osjetljivosti kod dječaka.

\section{Tablica 4.}

Deskriptivni podaci za cijelu ljestvicu i podljestvice dječje osjetlivosti na okolinu (DOO)

\begin{tabular}{lcccrrrr}
\hline & $N$ & $M(S D)$ & $\min -\max$ & asim. & \multicolumn{1}{c}{ splj. } & \multicolumn{1}{c}{$S E$} & $\mathrm{~S}-\mathrm{W}(p)$ \\
\hline DOO ukupni & 706 & $4.97(0.88)$ & $1-7$ & -0.18 & 0.09 & 0.03 & $0.99(.005)$ \\
Estetska osjetljivost & 708 & $5.94(0.83)$ & $1-7$ & -1.31 & 3.49 & 0.03 & $0.91(.000)$ \\
Nizak osjetni prag & 711 & $3.93(1.54)$ & $1-7$ & 0.08 & -0.74 & 0.06 & $0.98(.000)$ \\
Pobudljivost & 711 & $4.82(1.23)$ & $1-7$ & -0.38 & -0.25 & 0.05 & $0.98(.000)$ \\
\hline
\end{tabular}

Napomena: asim. - asimetričnost; splj. - spljoštenost; $S E$ - standardna pogreška asim. i splj.; S-W Shapiro-Wilkov test normaliteta distribucije.

\section{Rasprava}

Ovim su radom ispitane psihometrijske karakteristike Ljestvice DOO (Pluess i sur., 2018) u uzorcima hrvatske djece i adolescenata. Rezultati su pokazali da je 
Ljestvicom DOO moguće mjeriti individualne razlike u osjetljivosti na okolinu djece školske dobi (od 7 do 20 godina) u hrvatskome sociokulturnom kontekstu.

Potvrđena je bifaktorska struktura Ljestvice utvrđena u ranijim istraživanjima (Pluess i sur., 2018; Weyn i sur., 2019), s jednim faktorom opće osjetljivosti na okolinu i trima specifičnim faktorima: estetska osjetljivost, nizak osjetni prag i pobudljivost. Pouzdanost je cijele Ljestvice zadovoljavajuća. Korelacije rezultata na Ljestvici DOO i njezinim trima podljestvicama s rezultatima na upitniku IPIP-15 pokazuju da je osjetljivost na okolinu povezana s osobinama ličnosti iz modela „Velikih pet”, ali ne može se svesti na njih jer je najviša dobivena korelacija (između pobudljivosti i neuroticizma) .47 , što znači da dimenzije osjetljivosti na okolinu i osobine ličnosti ne dijele više od $22 \%$ varijance. Ti rezultati govore u prilog konvergentnoj i divergentnoj valjanosti Ljestvice DOO. Obrazac dobivenih korelacija u skladu je s obrascima utvrđenima u ranijim istraživanjima (Pluess i sur., 2018; Weyn i sur., 2019) i sugerira da dimenzija estetske osjetljivosti reprezentira osjetljivost na pozitivne aspekte okoline, dok dimenzije pobudljivosti i niskoga osjetnog praga reprezentiraju osjetljivost na negativne aspekte okoline. Naime, estetska osjetljivost pozitivno korelira s intelektom, ugodnošću, ekstraverzijom i savjesnošću - osobinama ličnosti koje su povezane s pozitivnom reaktivnošću i tendencijom prilaženja ugodnim i nagrađujućim iskustvima. Za razliku od toga, pobudljivost i nizak osjetni prag u pozitivnoj su korelaciji s neuroticizmom, a $\mathrm{u}$ negativnoj s ekstraverzijom (odnosno koreliraju pozitivno s introverzijom) osobinama ličnosti povezanima $s$ negativnom reaktivnošću $i$ tendencijom izbjegavanja neugodnih ili nenagrađujućih iskustava. Korelacije ukupnoga rezultata na Ljestvici s osobinama ličnosti (pozitivne $s$ neuroticizmom i intelektom te negativna s ekstraverzijom) u skladu su s teorijskom konceptualizacijom opće osjetljivosti na okolinu kao osobine ličnosti višega reda koja odražava osjetljivost na pozitivne i negativne aspekte okoline, odnosno obuhvaća ranjivost na izloženost negativnim čimbenicima $\mathrm{u}$ okolini $\mathrm{s}$ jedne strane i potencijal za profitiranje od izloženosti pozitivnim čimbenicima u okolini s druge strane (Pluess, 2015).

Unatoč tim rezultatima koji podržavaju korištenje cijele ljestvice čini se da podljestvice treba koristiti s oprezom. Dvije od podljestvica ne doprinose previše objašnjavanju cijele varijance $\left(\omega_{\mathrm{H}}\right)$, a kod pobudljivosti dodatni je problem što su dva od pet zasićenja neznačajna (Tablica 1.), čime je ugrožena sadržajna valjanost te podljestvice. Ti rezultati ne govore u prilog korištenju pobudljivosti i niskoga osjetnog praga kao zasebnih podljestvica. Za razliku od toga, o važnosti specifičnosti estetske osjetljivosti, osim teorijske podloge u obliku pozitivnih aspekata, govore i različita zasićenja općim i specifičnim faktorom, viši hijerarhijski omega, kao i ponešto drugačije korelacije s podljestvicama i ličnošću (Tablica 3.). Međutim, njezina je pouzdanost relativno niska te vjerujemo da bi daljnji razvoj instrumenta $\mathrm{s}$ naglaskom na tu podljestvicu mogao poboljšati istraživanja u tome području.

Raspršenja rezultata govore o dobroj osjetljivosti Ljestvice i znatnim individualnim razlikama u općoj osjetljivosti na okolinu koja obuhvaća osjetljivost na pozitivne i negativne podražaje i događaje kojima je osoba izložena. Osjetljivost 
na okolinu kontinuirana je osobina distribucija koje ne odstupa bitno od normalne distribucije, ali ranija istraživanja pokazuju da je korisno razlikovati podskupine pojedinaca različitoga stupnja osjetljivosti, popularno nazvane orhidejama, tulipanima i maslačcima (Aron i sur., 2012; Boyce i Ellis, 2005; Lionetti i sur., 2018; Pluess i sur., 2018). Stoga u budućim istraživanjima uz pristup usmjeren na kontinuirane dimenzije osjetljivosti na okolinu treba primijeniti i kategorijalni pristup.

Ljestvica DOO pokazala je djelomičnu mjernu invarijatnost u uzorcima djevojčica i dječaka te djece osnovnoškolske i srednjoškolske dobi, što je u skladu s ranijim nalazima (Weyn i sur., 2019) i omogućuje usporedbu njihovih rezultata u budućim istraživanjima na razini analize povezanosti, a za različite obrazovne razine i na razini prosječnih rezultata. Sposobnost Ljestvice da invarijatno mjeri osjetljivost na okolinu u vrlo širokome dobnom rasponu ključan je preduvjet za ispitivanje razvoja osjetljivosti na okolinu. Toj sposobnosti bitno doprinosi jednostavnost verbalne formulacije čestica koja omogućuje da i djeca najmlađe školske dobi razumiju tvrdnje te mogu dati valjane i pouzdane samoprocjene. Važno je istaknuti da su, u skladu s teorijskom konceptualizacijom konstrukta osjetljivosti na okolinu kao temeljnoga svojstva ljudi (i drugih živih bića) koje ih obilježava tijekom cijeloga životnog vijeka, Pluess i suradnici (2018) pri konstrukciji Ljestvice DOO krenuli od Ljestvice osjetljivosti na okolinu za odrasle (Aron i Aron, 1997), nastojeći konstruirati ljestvicu za djecu koja će sadržajno i strukturno biti usporediva s ljestvicom za odrasle. U tome su nastojanju uspjeli te se 12 čestica koje sačinjavaju Ljestvicu DOO verbalno neznatno razlikuje od čestica iz ljestvice za odrasle i grupira se u ista tri faktora koja su utvrđena u odrasloj dobi. U Nizozemskoj se Ljestvica DOO (prilagođena tako da su na pitanja odgovarale majke) pokazala dobrom mjerom osjetljivosti na okolinu i za djecu predškolske dobi (Slagt i sur., 2018). U budućim je istraživanjima potrebno ispitati mogućnost primjene Ljestvice DOO za mjerenje osjetljivosti na okolinu hrvatske djece predškolske dobi.

Rezultate ovoga istraživanja ograničava nekoliko metodoloških obilježja. Prvo ograničenje nastaje kao rezultat korištenja metode snježne grude za regrutiranje sudionika. Premda je korištenje te metode bilo opravdano zbog uvjeta lockdowna koji su bili na snazi u vrijeme prikupljanja podataka, ona ne dopušta visoku razinu kontrole nad sastavom uzorka i stoga se ne može pretpostaviti da su podaci prikupljeni na tome prigodnom uzorku reprezentativni za sve segmente populacije školske djece. $\mathrm{K}$ tomu, odsutnost informacija o nekim sociodemografskim obilježjima (npr. mjesto življenja i vrsta srednje škole) onemogućuje određivanje pristranosti uzorka. Treba napomenuti da te informacije nisu prikupljene zbog toga da cijeli upitnik koji su djeca ispunjavala ne bude predugačak i demotivirajuć za ispunjavanje. Drugo ograničenje proizlazi iz povijesnoga trenutka u kojemu su prikupljeni podaci - vremena lockdowna i nastave na daljinu zbog prvoga vala pandemije koronavirusa. Nažalost, nije moguće provjeriti na koji je način taj kontekst utjecao na strukturu uzorka i dobivene rezultate. $S$ jedne strane možemo pretpostaviti da su se $u$ istraživanje u većoj mjeri uključili učenici koji su se bolje prilagodili 
nastavi na daljinu te su, uz pojačane zahtjeve toga oblika nastave, imali interes i resurse za ispunjavanje online-upitnika. Opravdano je pretpostaviti da su to bili emocionalno stabilniji i savjesniji učenici. No s druge je strane tema istraživanja mogla više privući učenike koji su imali poteškoće u prilagodbi na promijenjen način života zbog pandemije, odnosno emocionalno nestabilne učenike. U budućim istraživanjima osjetljivosti na okolinu potrebno je osigurati reprezentativne uzorke. Treće, neke podljestvice upitnika IPIP-15 imale su vrlo niske procjene pouzdanosti, što je dijelom posljedica kratkoće upitnika. U budućim istraživanjima konvergentne i divergentne valjanosti Ljestvice DOO preporučljivo je primijeniti dulje upitnike ličnosti za koje se može bolje utvrditi pouzdanost, kao i rezultati na njihovim facetama. Korelacije rezultata na Ljestvici DOO s pojedinim facetama ličnosti mogu doprinijeti boljemu razumijevanju prirode osjetljivosti na okolinu. Četvrto, sve su varijable u ovome istraživanju izmjerene samoprocjenama, što rezultate opterećuje varijancom metode. U budućim primjenama Ljestvice DOO podatke je potrebno prikupiti iz više izvora, pri čemu je Ljestvicu moguće prilagoditi tako da se uz samoprocjene prikupe i procjene osoba koje dobro poznaju dijete (roditelji, braća i sestre, prijatelji). I peto, svi su podaci u ovome istraživanju prikupljeni u jednoj vremenskoj točki, zbog čega nije bilo moguće odrediti test - retest pouzdanost.

Zaključno, Ljestvica DOO pokazala je dobre psihometrijske karakteristike u uzorcima hrvatske djece $\mathrm{i}$ adolescenata te se na razini ukupnoga rezultata može preporučiti za korištenje u budućim istraživanjima. Njezina primjena i testiranje teorijskih postavki o moderacijskim učincima osjetljivosti na okolinu (Pluess, 2015) povećat će znanje o utjecaju različitih, pozitivnih i negativnih čimbenika iz okoline na razvoj i prilagodbu u djetinjstvu i adolescenciji. U situaciji trenutačne krize u Hrvatskoj izazvane pandemijom koronavirusa i potresima primjena Ljestvice DOO može omogućiti bolje razumijevanje i predviđanje dječjih reakcija na samu krizu, kao i na intervencije koje se poduzimaju da bi se smanjili njezini štetni učinci. U konačnici, poznavanje uloge osjetljivosti na okolinu u djetetovim reakcijama na pozitivne i negativne čimbenike iz okoline trebalo bi rezultirati povećanjem učinkovitosti psihosocijalnih intervencija i poboljšanjem psihičkoga zdravlja djece i adolescenata.

\section{Literatura}

Aron, E. N. i Aron, A. (1997). Sensory-processing sensitivity and its relation to introversion and emotionality. Journal of Personality and Social Psychology, 73(2), 345-368. https://doi.org/10.1037/0022-3514.73.2.345

Aron, E. N., Aron, A. i Jagiellowicz, J. (2012). Sensory processing sensitivity: A review in the light of the evolution of biological responsivity. Personality and Social Psychology Review, 16(3), 262-282. https://doi.org/10.1177/1088868311434213 
Belsky, J. (2013). Differential susceptibility to environmental influences. International Journal of Child Care and Education Policy, 7(2), 15-31. https://doi.org/10.1007/22886729-7-2-15

Belsky, J., Bakermans-Kranenburg, M. J. i van IJzendoorn, M. H. (2007). For better and for worse: Differential susceptibility to environmental influences. Current Directions in Psychological Science, 16(6), 300-304. https://doi.org/10.1111/j.1467-8721.2007.00525.x

Belsky, J. i Pluess, M. (2009). Beyond diathesis stress: Differential susceptibility to environmental influences. Psychological Bulletin, 135(6), 885-908. https://doi.org/10. 1037/a0017376

Boyce, W. T. i Ellis, B. J. (2005). Biological sensitivity to context: I. An evolutionarydevelopmental theory of the origins and functions of stress reactivity. Developmental Psychopathology, 17(2), 271-301. https://doi.org/10.1017/s0954579405050145

Cassidy, J., Woodhouse, S., Sherman, L., Stupica, B. i Lejuez, C. (2011). Enhancing infant attachment security: An examination of treatment efficacy and differential susceptibility. Development and Psychopathology, 23(1), 131-148. https://doi.org/10. 1017/S0954579410000696

Chen, F. F. (2007). Sensitivity of goodness of fit indexes to lack of measurement invariance. Structural Equation Modeling: A Multidisciplinary Journal, 14, 464-504. https://doi.org/10.1080/10705510701301834

De Haan, A., Prinzie, P. i Deković, M. (2010). How and why children change in aggression and delinquency from childhood to adolescence: Moderation of overreactive parenting by child personality. Journal of Child Psychology and Psychiatry, 51(6), 725-733. https://doi.org/10.1111/j.1469-7610.2009.02192.x

de Villiers, B., Lionetti, F. i Pluess, M. (2018). Vantage sensitivity: A framework for individual differences in response to psychological intervention. Social Psychiatry and Psychiatric Epidemiology, 53, 545-554. https://doi.org/10.1007/s00127-017-1471-0

Dunn, T. J., Baguley, T. i Brunsden, V. (2014). From alpha to omega: A practical solution to the pervasive problem of internal consistency estimation. British Journal of Psychology, 105(3), 399-412. https://doi.org/10.1111/bjop.12046

Ellis, B. J. i Boyce, W. T. (2008). Biological sensitivity to context. Current Directions in Psychological Science, 17(3), 183-187. https://doi.org/10.1111/j.1467-8721.2008. 00571.x

Ellis, B. J., Essex, M. J. i Boyce, W. T. (2005). Biological sensitivity to context: II. Empirical explorations of an evolutionary-developmental theory. Developmental Psychopathology, 17(2), 303-328. https://doi.org/10.1017/s0954579405050157

Garrido, L. E., Abad, F. J. i Ponsoda, V. (2013). A new look at Horn's parallel analysis with ordinal variables. Psychological Methods, 18(4), 454-474. https://doi.org/10.1037/ a0030005

Hanzec, I., Wertag, A. i Vujnović Malivuk, K. (2017). Early family experiences and wellbeing in emerging adulthood: Investigating the role of sensory processing sensitivity and adult attachment. U: I. Burić (Ur.), 20 th Psychology Days in Zadar-Book of selected proceedings (str. 51-58). University of Zadar. 
Ho, M. Y., Cheung, F. M., You, J., Kam, C., Zhang, X. i Kliewer, W. (2013). The moderating role of emotional stability in the relationship between exposure to violence and anxiety and depression. Personality and Individual Differences, 55(6), 634-639. https://doi.org/10.1016/j.paid.2013.05.004

Keresteš, G. (2006). Children's aggressive and prosocial behavior in relation to war exposure: Testing the role of perceived parenting and child's gender. International Journal of Behavioral Development, 30(3), 227-239. https://doi.org/10.1177/0165025406066756

Kim, S. i Kochanska, G. (2012). Child temperament moderates effects of parent-child mutuality on self-regulation: A relationship-based path for emotionally negative infants. Child Development, 83(4), 1275-1289. https://doi.org/10.1111/j.1467-8624.2012. 01778.x

Kuterovac Jagodić, G. (2003). Posttraumatic stress symptoms in Croatian children exposed to war: A prospective study. Journal of Clinical Psychology, 59(1), 9-25. https://doi.org/10.1002/jclp.10114

Little, T. D. (2013). Longitudinal structural equation modeling. The Guilford Press.

Lionetti, F., Aron, A., Aron, E. N., Burns, G. L., Jagiellowicz, J. i Pluess, M. (2018). Dandelions, tulips and orchids: Evidence for the existence of low-sensitive, mediumsensitive and high-sensitive individuals. Translational Psychiatry, 8(24), 1-11. https://doi.org/10.1038/s41398-017-0090-6

McDonald, R. P. (1999). Test theory: A unified treatment. Erlbaum.

Mlačić, B., Milas, G. i Kratohvil, A. (2007). Adolescent personality and self-esteem - An analysis of self-reports and parental-ratings. Društvena istraživanja, 16(87-88), 213236. https://hrcak.srce.hr/18928

Monroe, S. M. i Simons, A. D. (1991). Diathesis-stress theories in the context of life stress research: Implications for the depressive disorders. Psychological Bulletin, 110(3), 406425. https://doi.org/10.1037/0033-2909.110.3.406

Nocentini, A., Menesini, E. i Pluess, M. (2018). The personality trait of environmental sensitivity predicts children's positive response to school-based antibullying intervention. Clinical Psychological Science, 6(6), 848-859. https://doi.org/10.1177/ 2167702618782194

O’Connor, B. P. (2000). SPSS and SAS programs for determining the number of components using parallel analysis and Velicer's MAP test. Behavior Research Methods, Instruments, \& Computers, 32(3), 396-402. https://doi.org/10.3758/BF03200807

Pluess, M. (2015). Individual differences in environmental sensitivity. Child Development Perspectives, 9(3), 138-143. https://doi.org/10.1111/cdep.12120

Pluess, M. (2017). Vantage sensitivity: Environmental sensitivity to positive experiences as a function of genetic differences. Journal of Personality, 85(1), 38-50. https://doi.org/10. 1111/jopy.12218

Pluess, M. (2020). Protocol for the translation of questionnaires. Queen Mary University. Sensitivityresearch.com

Pluess, M. i Belsky, J. (2009). Differential susceptibility to rearing experience: The case of childcare. Journal of Child Psychology and Psychiatry and Allied Disciplines, 50(4), 396-404. https://doi.org/10.1111/j.1469-7610.2008.01992.x 
Pluess, M. i Belsky, J. (2013). Vantage sensitivity: Individual differences in response to positive experiences. Psychological Bulletin, 139(4), 901-916. https://doi.org/10.1037/ a0030196

Pluess, M., Assary, E., Lionetti, F., Lester, K. J., Krapohl, E., Aron, E. N., i Aron, A. (2018). Environmental sensitivity in children: Development of the Highly Sensitive Child Scale and identification of sensitivity groups. Developmental Psychology, 54(1), 51-70. https://doi.org/10.1037/dev0000406

Putnick, D. L. i Bornstein, M. H. (2016). Measurement invariance conventions and reporting: The state of the art and future directions for psychological research. Developmental Review, 41, 71-90. https://doi.org/10.1016/j.dr.2016.06.004

R Core Team. (2017). R: A language and environment for statistical computing. R Foundation for Statistical Computing. https://www.R-project.org/

RStudio Team. (2016). RStudio: Integrated Development for R. Boston: RStudio. http://www.rstudio.com/

Raboteg-Šarić, Z., Merkaš, M. i Miljević, T. (2018). Family relations and relationships with peers as determinants of self-esteem in adolescents. Central European Journal of Paediatrics, 14(2), 190-200. https://doi.org/10.5457/p2005-114.218

Rajhvajn Bulat, L., Sušac, N. i Ajduković, M. (2019). Doprinos nekih osobnih i okolinskih varijabli u objašnjavanju eksternaliziranih problema adolescenata. Društvena istraživanja, 28(2), 271-293. https://doi.org/10.5559/di.28.2.05

Reise, S. P., Bonifay, W. E. i Haviland, M. G. (2013). Scoring and modeling psychological measures in the presence of multidimensionality. Journal of Personality Assessment, 95, 129-140. https://doi.org/10.1080/00223891.2012.725437

Rončević Zubković, B., Kolić-Vehovec, S., Smojver-Ažić, S., Martinac Dorčić, T. i PahljinaReinić, R. (2020). The role of experience during playing bullying prevention serious game: Effects on knowledge and compassion. Behaviour \& Information Technology. https://doi.org/10.1080/0144929X.2020.1813332

Satorra, A. i Bentler, P. M. (2001). A scaled difference chi-square test statistic for moment structure analysis. Psychometrika, 66, 507-514.

Slagt, M., Dubas, J. S., Deković, M. i van Aken, M. A. (2016). Differences in sensitivity to parenting depending on child temperament: A meta-analysis. Psychological Bulletin, 142(10), 1068-1110. https://doi.org/10.1037/bul0000061

Slagt, M., Dubas, J. S., Denissen, J. J., Deković, M. i van Aken, M. A. (2015). Personality traits as potential susceptibility markers: Differential susceptibility to support among parents. Journal of Personality, 83(2), 155-166. https://doi.org/10.1111/jopy.12091

Slagt, M., Dubas, J. S., van Aken, M. A., Ellis, B. J. i Deković, M. (2018). Sensory processing sensitivity as a marker of differential susceptibility to parenting. Developmental Psychology, 54(3), 543-558. https://doi.org/10.1037/dev0000431

Sušac, N., Ajduković, M. i Rimac, I. (2016). Učestalost vršnjačkog nasilja s obzirom na obilježja adolescenata i doživljeno nasilje u obitelji. Psihologijske teme, 25(2), 197-221. https://hrcak.srce.hr/161862 
Vizek-Vidović, V., Arambašić, L., Keresteš, G., Kuterovac Jagodić, G. i Vlahović-Štetić, V. (2001). Pet ownership in childhood and socio-emotional characteristics, work values and professional choices in early adulthood. Anthrozoos, 14(4), 224-231. https://doi.org/10.2752/089279301786999373

Weston, R. i Gore, P. A. (2006). A brief guide to structural equation modeling. The Counseling Psychologist, 34, 719-751. https://doi.org/10.1177/0011000006286345

Weyn, S., Leeuwen, K., Pluess, M., Lionetti, F., Greven, C., Goossens, L., Colpin, H., Noortgate, W., Verschueren, K., Bastin, M., Hoof, E. V., Fruyt, F. i Bijttebier, P. (2019). Psychometric properties of the Highly Sensitive Child Scale across developmental stage, gender, and country. Current Psychology, 1-17. https://doi.org/10.1007/s12144019-00254-5

Zadro, K. (2020). Dodana prediktivna valjanost osobina mračne trijade u odnosu na petofaktorski model pri predviđanju individualnih razlika u samopoštovanju. [Diplomski rad]. Odsjek za psihologiju Filozofskog fakulteta u Zagrebu.

\title{
Psychometric Properties of the Highly Sensitive Child Scale in Samples of Croatian Children and Adolescents
}

\begin{abstract}
Environmental sensitivity refers to how readily one registers and how deeply one processes information from the environment. Individual differences in environmental sensitivity determine an individual's reactions to positive and negative environmental influences. The role of environmental sensitivity in children's development has been underresearched, in large part because the first direct measure of children's environmental sensitivity has only recently been developed. The aim of this study is to examine the psychometric properties of this measure - the Highly Sensitive Child (HSC) Scale (Pluess et al., 2018) - in Croatia. As part of the project How are we? Life in Croatia in the age of Coronavirus, primary $(N=407)$ and secondary $(N=307)$ school-aged children completed the HSC Scale and the IPIP-15 via an online survey. The HSC Scale, a self-report measure of environmental sensitivity, demonstrated satisfactory reliability and validity levels among Croatian children and adolescents. The scale has a bifactor structure and measures general environmental sensitivity and three specific dimensions: aesthetic sensitivity, low sensory threshold and ease of excitation. Partial measurement invariance for children of different genders and ages was confirmed. Correlations of subscales and general environmental sensitivity with personality traits are moderate and theoretically meaningful. The scale demonstrated good psychometric characteristics and is recommended for use in future research, although further research on the subscales is needed. Application of this scale can contribute to knowledge about the effects of positive and negative environmental influences on the development of children and adolescents.
\end{abstract}

Keywords: HSC scale, reliability, validity, confirmatory factor analysis, measurement invariance

Primljeno: 27. 1. 2021. 